\title{
Influence of the Merger of Universities to the Brand
}

Novenkova A. Z.

\author{
Kazan (Volga region) federal university, Kazan, 420008, Russia
}

\section{Doi:10.5901/mjss.2014.v5n18p39}

\begin{abstract}
In this study, the canibalization of university brands in the process of enlargement and merger is seen as a conscious strategy in favor of the most modern and cost-effective products when more sophisticated and marketable product "sucks" and replaces outdated and less attractive to the consumer. The brand cannibalization is discussed in the context of internal competition between subdivisions of an merged institution having one scientific orientation. At some point cannibalization might become a strategic management option in the process of restructuring.
\end{abstract}

Keywords: branding, restructuring, strategy brand cannibalization, higher education.

The terms "brand cannibalization", "trademark cannibalization" started to be used rather recently. They are supposed to have appeared due to the reformation of the Russian economy and appearance of many enterprises which successfully produce and sell goods under different trademarks [1]. Brand cannibalization, or brand takeover, is quite common in the market economy where, by analogy with the Darwin's theory, the strongest survives. A trademark that does not correspond to the "environment" should either adapt to it, using all its strengths, or disappear.

Cannibalization in marketing implies negative influence of sales of one product on the image of another product of the same enterprise within the umbrella brand [2]. In some cases "cannibalization" is a conscious strategy of the manufacturer in favor of new and more profitable products, when the improved product "merges" a less perfect one. Everything depends on how two products (the cannibal and the victim) correlate with each other. If they are absolutely identical by their consumer-oriented characteristics, including price, then it is necessary only to take into account the victim's stock goods to be sold before the cannibal enters the market. If the cannibal and the victim differ (at least, in something) one should evaluate the possibilities of the cannibal and victim's co-existence in the frames of one market in order to develop a strategy to bring the cannibal to market. In all situations they influence each other in one market since the number of consumers is constant. However, if the cannibal outperforms the victim the quantity of consumers will significantly increase.

Brand cannibalization in the market conditions implies that a brand is sold at the expense of another brand of the same company. The cannibal product reduces the market share of the victim product, thus making the company's promotion spending ineffective. In other words, cannibalization implies negative consequences of line extension [3].

It is of particular interest to study the process of brand cannibalization in education. All-Russian tendency to amalgamate institutions of higher education by merging several universities presupposes integrating higher schools with well -established history, practice and image. Moreover, some universities are restructured before integrating into enlarged institutions, thus getting off their beat.

Over the last 10 years, the functioning of the Russian educational system has been characterized by complicated qualitative changes. One may say that by the present moment Russian traditional unitary educational system has been turned into a multi-level optional model in the context of joining to the Bologna Convention. Generally, experts approve the integrating process in the educational sphere since it generates a higher return from education.

This measure is necessary to develop institutions of higher education in the modern economic conditions. This process started in the world at the beginning of the 1990s; Russia is coming up as usual.

It is evident that merger - by definition - cannot be painless: the procedure is complicated from the technical as well as from human point of view. Thus, "duplicating" departments appear in the process of merger. However, the increasing number of departments is less harmful than the emergence of two identical structural units. This problem is solved differently in different universities. There is a strategy when identical departments are simply merged. In some universities these departments continue to exist in duplicity. In this case the strategy of the executive management is aimed at creating staff competition, which is not always a good decision as far as it increases tension among personnel and does not promote well-coordinated work. In some cases it even causes sabotage. 
The transition of our country to market economy is accompanied by an employment crisis resulting from uncontrolled training of higher education professionals. The crisis is characterized by a surplus in economists, lawyers and managers, on the one hand, and labor shortage, on the other hand. The recognition of this fact led to the reforming of the country's educational system. The reform is aimed at creating a system of lifelong learning which corresponds, on the one hand, to the human needs and, on the other hand, to the requirements of national economy. Today, Russian educational system is undergoing deep changes connected with its transition to an integrated, multi-level educational model which ensures consistency of all its components (pre-vocational, elementary, secondary, higher and postgraduate), forms and institutions [4].

At the same time modern demographic situation characterized by sociologists as a demographic crisis is getting worse. This trend is expected to continue in the foreseeable future. Therefore, all Russian institutions of higher education are operating in an increasingly competitive environment struggling for enrollees. Tension is sure to increase. Consequently, a detailed investigation of this market sector as well as of the methods to attract consumers of educational services is as relevant as never before.

As a whole, all the current changes result in burning competition in the market of educational services. In this situation, universities with strong brand image have a better chance of success. Being the most advanced and effective way to attract consumers' attention, branding meets these challenges and responds to the threats in the best way. Universities should grasp the importance of branding as a tool to make decisions and to attract enrollees.

In the field of higher education branding is definitely different from that in commercial sphere. It has some peculiarities, but the essence is the same: it implies a positive image of a university, its bright individual and original style valuable for consumers of educational services. All these will enable the institution to consolidate its position in the market and to attract enough enrollees with strong learning motivation.

In Russia branding in the sphere of educational services presents a serious managerial problem. There is one more aspect closely connected with brand cannibalization in education. That is existence of several colleges with similar research areas within one enlarged (for example, federal) university. As a result there is a painful situation when two similar structures have to fight with each other for enrollees and financing. All this undermines the brand image of the university which is undergoing reorganization as it is. Merged universities face a lot of problems, such as existence of several colleges with similar research areas, strong emotional attachment of newly created departments to the old-style patterns of work, reluctance or inability of middle managers to integrate into the new entity, etc. All these result in an ailing competitive atmosphere in the merged university. It hinders the development of viable corporative culture, makes attempts to apply strategies of marketing communications fruitless and, ultimately, damages the brand image of the new university in the eyes of consumers.

In other words, it is difficult to uphold the reputation of a brand leader under the conditions of the 'cold war' for power and quantitative and qualitative indicators. In this situation the brand image really matters for enrollees. A lot of future students respond, first of all, to the educational brands of the 'before merger' times which discredits the idea of quality education.

Thus, in the process of creating a strong brand image of a newly merged university it seems unreasonable to have several departments with similar research areas in its structure. In some cases cannibalization can be a conscious strategy aimed at getting the most up-to-date and cost-efficient educational product. In this case a more advanced and popular college or faculty "merges" its rivals and, consequently, will be able to create a new strong brand supported by its managerial and structural superiority.

\section{References}

Wendy Lomax, Kathy Hammond, Robert East, Maria Clemente, (1997) "The measurement of cannibalization", Journal of Product \& Brand Management, Vol. 6 Iss: 1, pp.27 - 39

Safiullin N.Z., Gafurov I.R., Safiullin L.N., Odintsova U.L. Modern Information Resources in Education// Mediterranean Journal of Social Sciences.- Vol.5, No12, (2014)-pp.113-116.

Safiullin, M.R., Eflova M.U., Nagimova A.M. (2012). Social well-being and self-identification of the middle class in the Republic of Tatarstan. Sociologicheskie issledovaniya, 9, 28-32.

Safiullin, N.Z., Safiullin, L.N. (2013) The measure proximity in welfare theory // World Applied Sciences Journal 26 (4) PP. 449 - 453, doi: 10.5829/idosi.wasj.2013.26.04.13472

Bagautdinova N.G., Nayda A.M., Hayrullin B.A., Arzhantseva N. Behaviour of Households on Financial Investments Market/l Mediterranean Journal of Social Sciences.- Vol.5, No12, (2014)-pp.103-106.

Panasyuk, M.V., Gafurov, I.R., Novenkova, A.Z. Influence of international transport and logistics systems on economic development of the region // World Applied Sciences Journal, 27(13), 2013, 135-139. 
Gafurov I.R., Platonova O.U., Pratchenko O.V. New State Economic Policy - Cluster Policy Cluster Policy as the Factor of Innovative Development of Europe// Mediterranean Journal of Social Sciences.- Vol.5, No12, (2014)-pp.107-112.

Averianov, B.A., Bagautdinova, N.G., Sarkin, A.V. Estimation of manufacturing enterprise development risks in process of operational activity // World Applied Sciences Journal, 27(13), 2013, 202-206.

Bagautdinova, N., Gafurov, I., Kalenskaya, N., Novenkova, A. The regional development strategy based on territorial marketing (The Case of Russia) // World Applied Sciences Journal, 18(Issue SPL.ISSUE. 18), 2012, 179-184.

Kirshin I.A. Modeling the long-term trend of accumulation of knowledge. Life Science Journal 2014; 11(6s): $482-486$.

Sarkin, A.V., Bagautdinova, N.G., Fazlieva, E.P., Averianov, B.A. Development and implementation of machinery building enterprises complex development strategies in the contexts of the contemporary Russian economy institutes // World Applied Sciences Journal, 27(13), 2013, 174-179.

Safiullin L.N., Gafurov I.R., Shaidullin R.N., Safiullin N.Z. Socio-economic development of the region and its historical and cultural heritage. Life Science Journal 2014; 11(6s): 400-404.

Poltoradneva N.L. Terminological basis of financial engineering: comparative analysis of the definitions "financial product" and "financial instrument". Life Science Journal 2014; 11(6s): 490-493.

Gibadullin M.Z. Fazlieva E.P. Nurieva A.R. Grigoryeva L.L Territorial Aspects of Migration Processes in Russia// Mediterranean Journal of Social Sciences.- Vol.5, No12, (2014) -pp.93-96. 
